\title{
The mediating role of emotion regulation between childhood-adolescence socioeconomic status and cardiovascular diseases in middle age: Path analysis
}

\author{
$\underline{\text { SM. Hakak }}^{1}$, AR. Kakavand ${ }^{2}$, HR. Javadi ${ }^{3}$
}

\footnotetext{
${ }^{1}$ Social Faculty, Imam Khomeini International University, Qazvin, Iran

${ }^{2}$ Department of Psychology, Social Faculty, Imam Khomeini International University, Qazvin, Iran

${ }^{3}$ Department of Cardiology, Faculty of Medicine, Qazvin University of Medical Science, Qazvin, Iran

Corresponding Address: Seyede Mansoureh Hakak, Imam Khomeini International University, Qazvin, Iran Tel: +98-912-782-7116; Email: s.m.hakak.21@gmail.com

Received: 2 Jun 2018; Accepted: 22 Jul 2018
}

\section{* Abstract}

Background: World Health Organization considers to control the cardiovascular diseases as health priority in developing countries. Life course is a biopsychsocial approach to chronic diseases and childhood-adolescence is a major course for development of this diseases.

Objective: The aim of this study was to determine the mediating role of cognitive emotion regulation in relationship between childhood-adolescence socioeconomic status and cardiovascular risk factors in middle age.

Methods: This descriptive-correlational study was conducted in Cardiology Department of Bu-Ali Sina Hospital in Qazvin in 2017. Two hundred five middle age persons were chosen by judgmental sampling. The study tools were childhood-adolescence socioeconomic status researcher-made questionnaire, Garnefski cognitive emotion regulation scale and Framingham 10 year risk assessment of cardiovascular disease. Data were analyzed by path analysis.

Findings: Results demonstrated that negative cognitive emotion regulation mediated the relationship between childhood-adolescence socioeconomic and cardiovascular diseases status. The direct effect of childhood-adolescence socioeconomic status on negative cognitive emotion regulation and this negative cognitive emotion regulation on the cardiovascular disease were approved.

Conclusion: Likely, policies for improving socioeconomic status in childhood-adolescence and interventions teaching for the appropriate emotion regulation can stop the development of cardiovascular disease risk and play a basic role in prevention of it.

Keywords: Socioeconomic status, Cardiovascular diseases, Emotion

Citation: Hakak SM, Kakavand AR, Javadi HR. The mediating role of emotion regulation between childhood-adolescence socioeconomic status and cardiovascular diseases in middle age: Path analysis. J Qazvin Univ Med Sci 2018; 22(4): 63-73. 


\title{
نقش ميانجى تنظيم هيجان در وضعيت اجتماعى-اقتصادى كودكى -نوجوانى و ابتلا به بيمارى هاى قلبى -عروقى در ميانسالى: تحليل مسير إنى
}

\author{
سيده منصوره حكاك'، دكتر عليرضا كاكاوند'، دكتر حميدرضا جوادى'
}

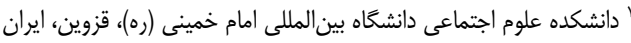

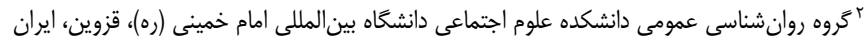

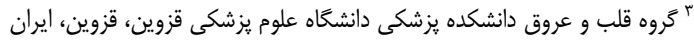

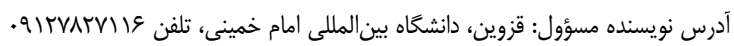

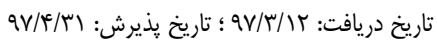

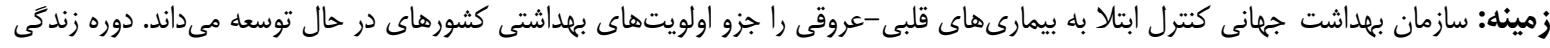

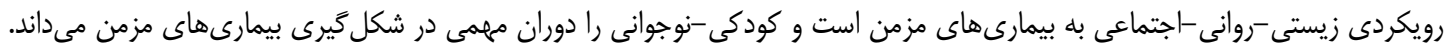

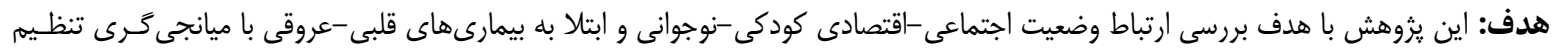
هيجان، اجرا شد.

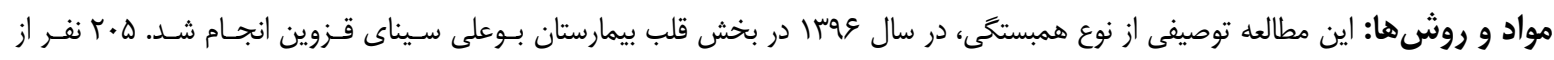

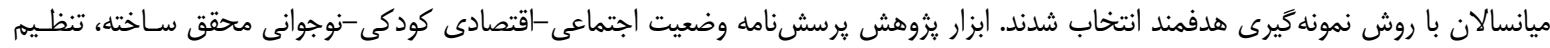

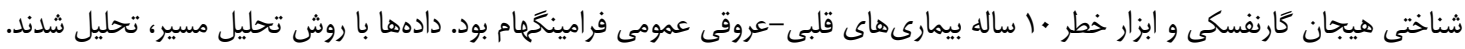

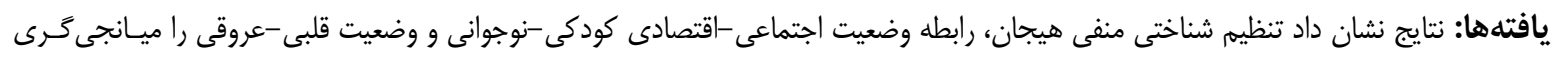

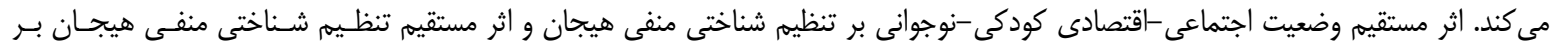
وضعيت قلبى -عروقى تأييد شد.

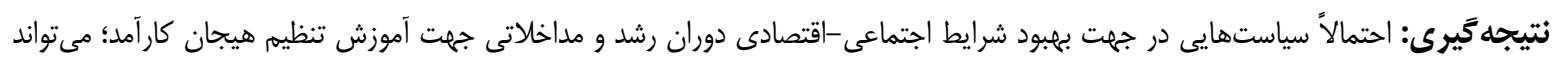

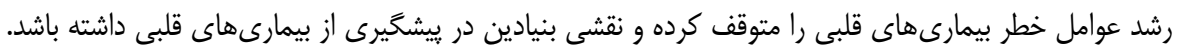

كليدوازهها: وضعيت اجتماعى-اقتصادى، بيمارىهاى قلبى-عروقى، هيجان

مقدمه:

كرده و در ميانسالى و سالمندى بروز مىيابند. لذا كودكى نوجوانى مؤثرترين زمان در شكل ميرى بيمارى

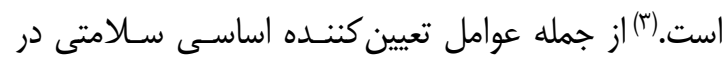

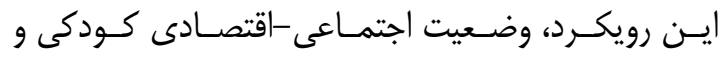

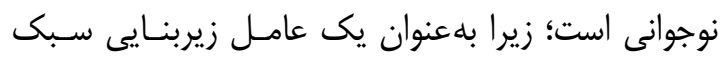
زندگى، ميزان تنش و نوع واكنش به آن، تغذيه، رفتارهاى

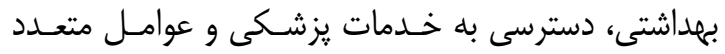

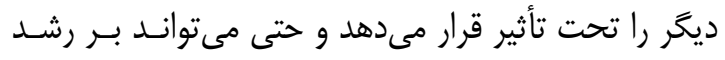
زبانى و شناختى كودكان تأثير قابل توجهى بحتذارد.
بيمارىهاى قلبى-عروقى از بيمارىهاى غيرواگير اصلى

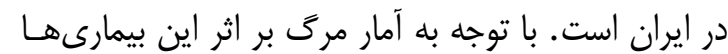

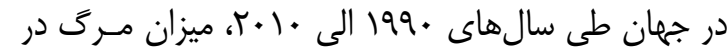

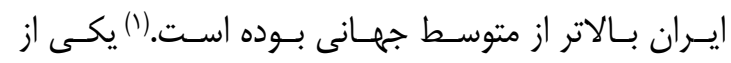

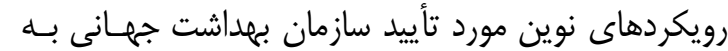
مفهوم بيمارى رويكرد دوره زندگى است. اين رويكرد اولاًا

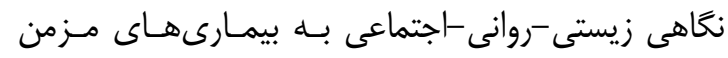

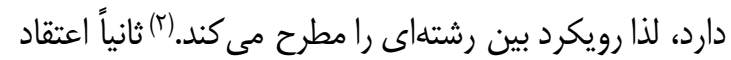
دارد عوامل مذكور از اوايل زندكى اثر كذارى خـود را آغــاز 
زيستى را نيز تغيير دهد. اين شرايط مسىتوانـــ منجـر بــهـ

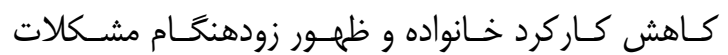

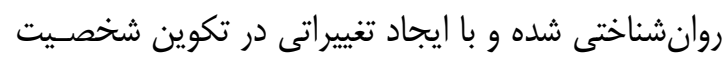

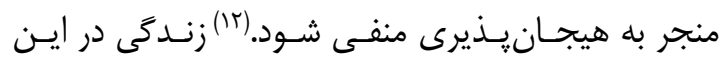

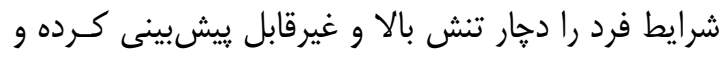

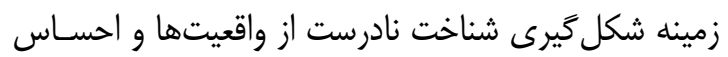

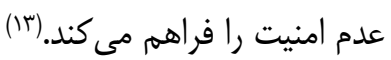

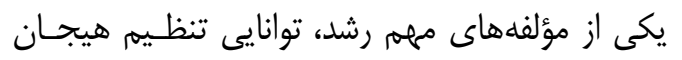

است. شناخت منفى به محيط سبب مىشود فرد بيشتر از

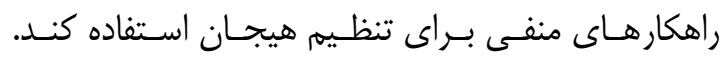

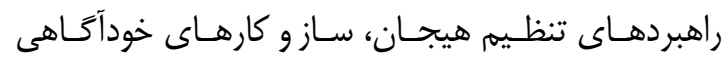

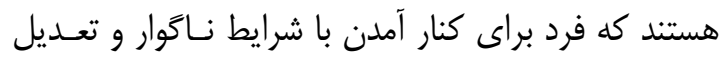
هيجان بهكار مىبرد كه به دو دسته مثبت و منفى تقسيهم

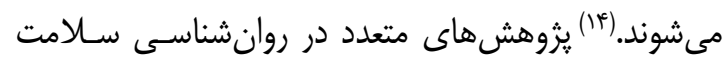

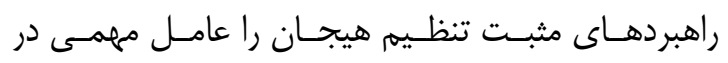

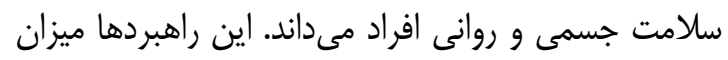

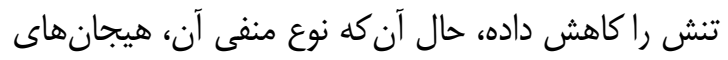

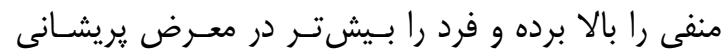

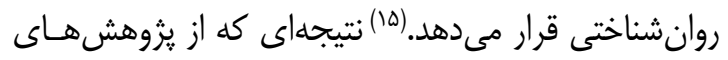
متعدد مىتوان بيان كرد اين است كه تنش در آسيبذيذيرى

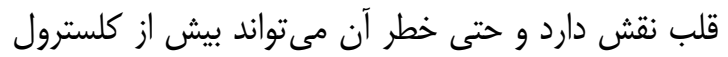

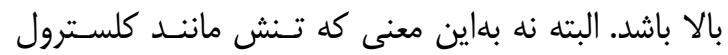

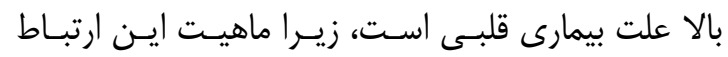
يبيجيده بوده و عوامل خطر اين بيمارىها متعدد است. يزوهشهاى متعدد نشان مىدهد تنش موجب تغييرات

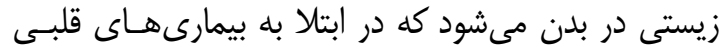

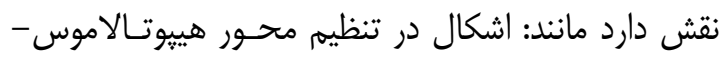

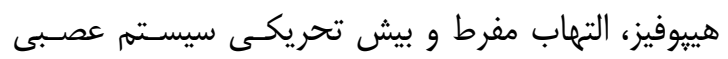

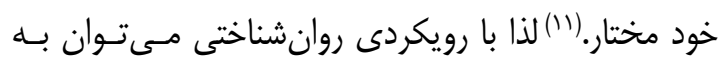
اين بيمارى جسمى نخريست. يزوهشها از ارتباط وضعيت

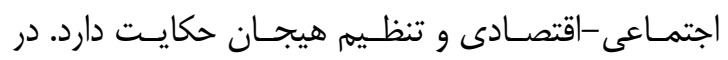

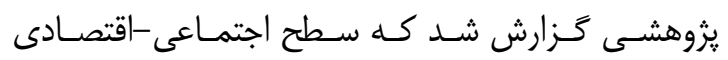
ييشبين اساسـى تنظيم هيجـان اسـت و سـطح بـالاى

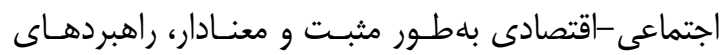

رابطه شـيبدار ميـان وضـعيت اجتمـاعى -اقتصـادى و

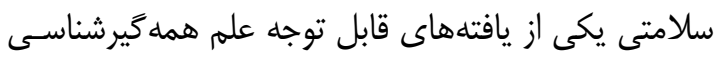

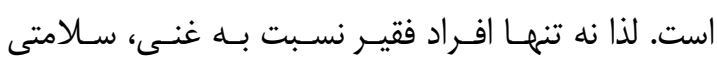

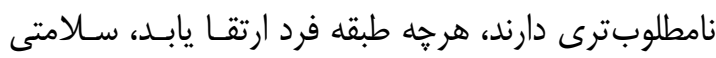

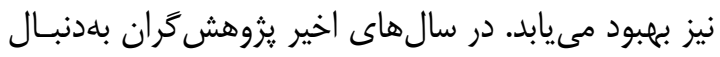

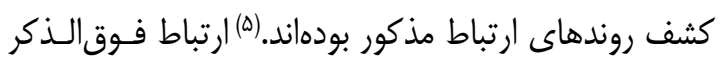
در جوامع مختلفى مانند؛ آمريكاى لاتسين، آمريكـا، ارويـا،

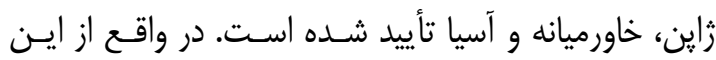

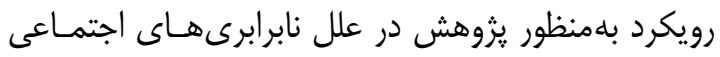

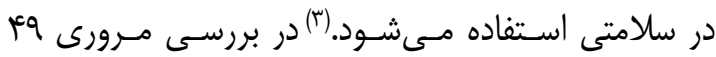

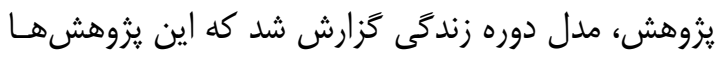

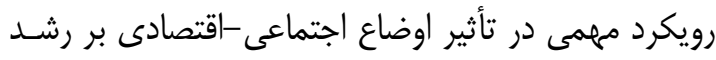

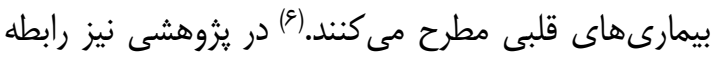
معكوس وضعيت اجتماعى -اقتصادى دوران رشـــ و ابـتلا به بيمارى عروق كرونر تأييد شد. در يزوهشى وضعيت اجتماعى -اقتصادى فوت شدكان

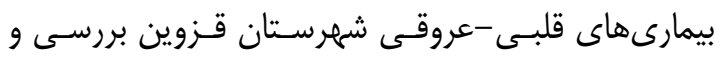

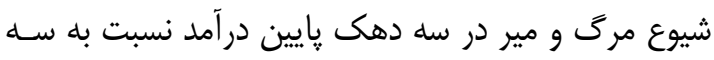

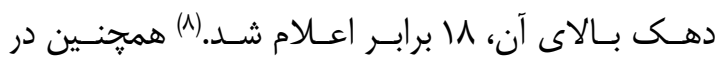

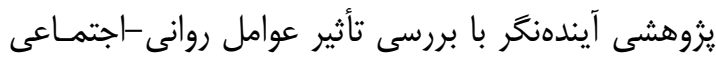
مطلوب دوران رشد بر سلامتى ايدهآل قلبى -عروقى افراد

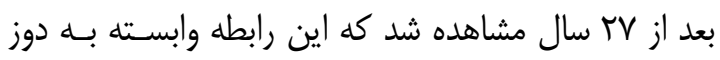

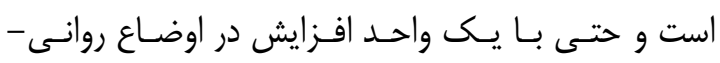
اجتماعى، فرد از سلامتى بهتر قلب برخوردار خواهد الهد بود. عوامل روانشناختى نقش واسطهاى مهمى در ايــن ميـان

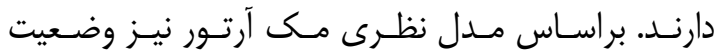

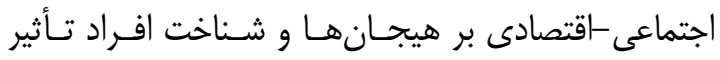

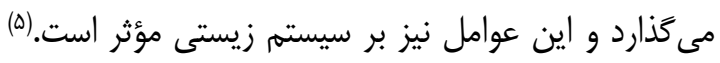

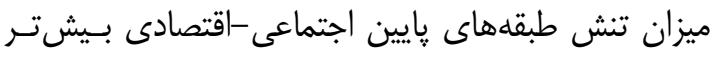

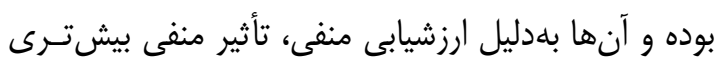

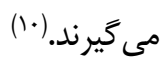

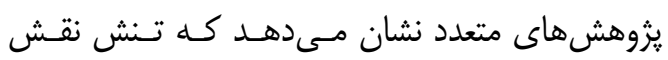

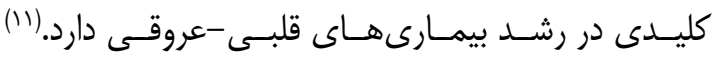
تنشهاى طبقه اجتماعى در كودكى ممكن است سيسـتم 
وضعيت اجتمـاعى -اقتصـادى و ســندرم متابوليـك تأييـد

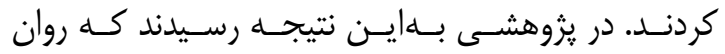

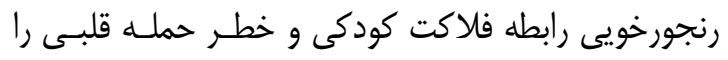

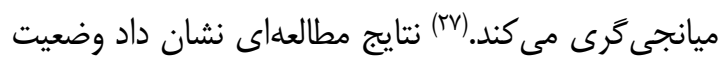

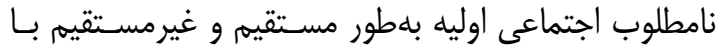
خطر بيمارىهاى قلبى -عروقى متابوليك بزر كسالى رابطه

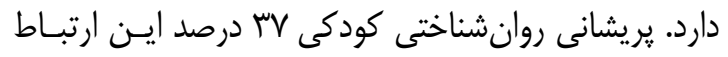

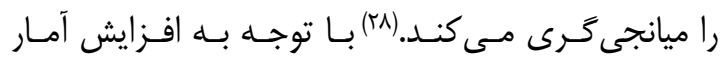
بيمارىهاى قلبى در ايران و رواج رويكرد دوره زنـدگى در سطح جهـانى، لـزوم يـروهش در ايـن موضـوع احسـاس

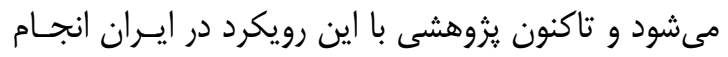
نشده است. لذا اين مطالعه بهدنبال مدلى است كه ارتبـاط

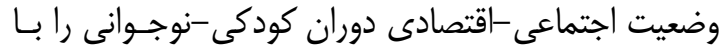
ابتلا به بيمارىهاى قلبى -عروقى با ميانجى گترى تنظيم هيجان بررسى كند.

\section{0 مواد و روشها:}

يــروهش حاضــر از نــوع توصـيفى و داراى الخــــى

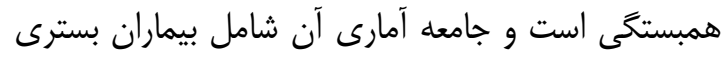

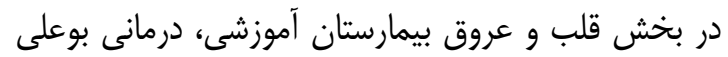

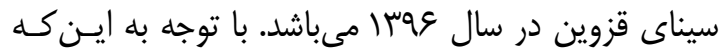
طرح يزوهش حاضر از نوع همبستخى بوده و به يك كروه

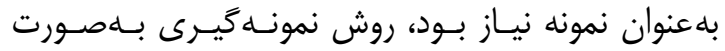

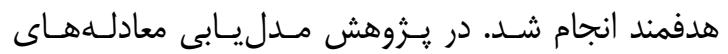
ساختارى و تحليل مسير با توجه به نظر تاباكنيك و فيدل

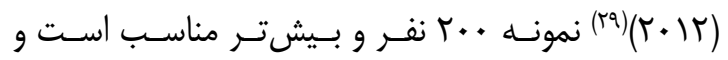

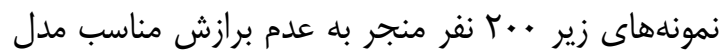

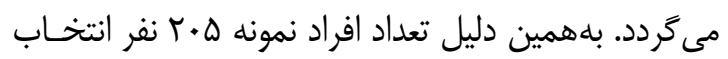

معيـار ورود بــه يـزووهش، سـن • أ سـال و بــالاتر و

موافقت و رضايت بيمار و معيار خـروج از مطالعـه عبـارت بودند از: سابقه بيمارى قلبى -عروقى در كودكى، نوجـوانى

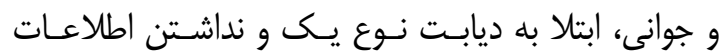

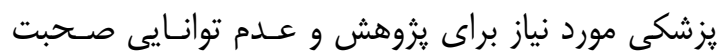

مثبت تنظيم هيجان و بهزيستى روانشـناختى و بـهـطـور

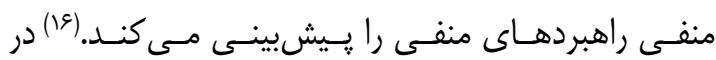

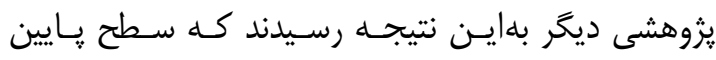

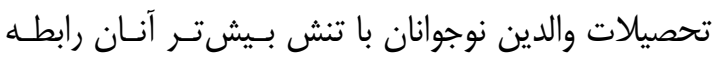
دارد، اين نوجوانان كمتر خوشبين هستند و ايـن بـديبنى مىتواند متغير واسطهاى بين وضعيت اجتماعى-اقتصـادى

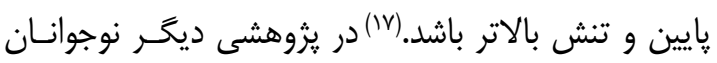

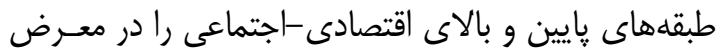
فيلمى با موقعيتهاى مبهم قرار داده و ديدند كه نوجوانان طبقهاى بايين نسبت به بالا بيشتر تفسير منفى كرده و

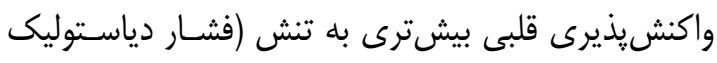
بالا و ضربان قلب بالاتر) داشتند. (ir) بيلك و ميو (ها +r) نيز ميان سطح اجتماعى -اقتصادى مكانى كه فرد در كودكى زندگى مى كند و دشوارى تنظيم

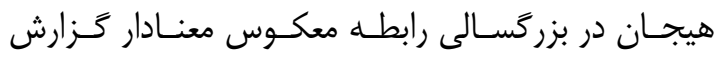

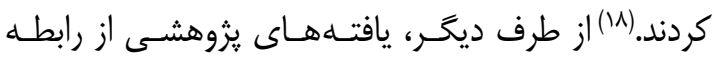
تنظيم هيجـان و وضـعيت قلبـى -عروقى حكايست دارد. محققان بهاين نتيجه رسيدند كه طـرحوارههـاى ناسـاز كار

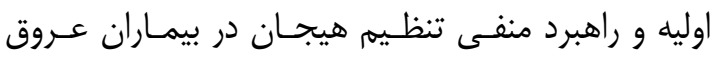
كرونر نسبت به افراد سالم بلهطور معنــادار بـالاتر بـود. يزوهش گران كزارش كردند كه افراد سـالم نسـبت بــه دو

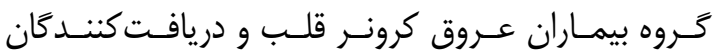

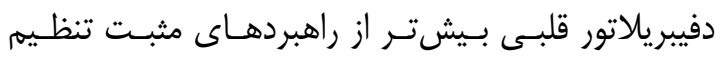

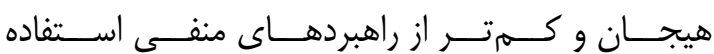

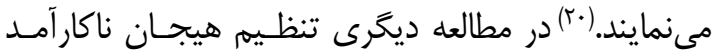
عامل خطر ابتلا به بيمـارىهـاى قلبـى -عروقى بـوده و

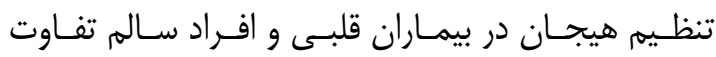
(II).

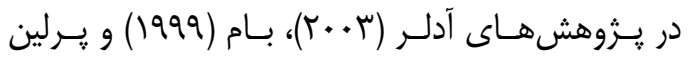

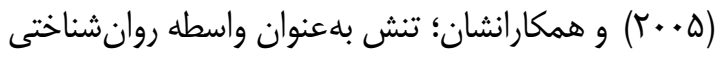

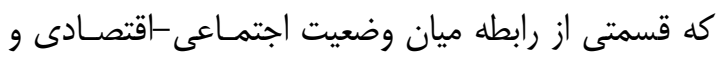

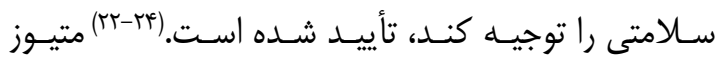

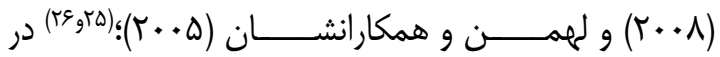
يزوهشهاى خود نقش واسطهاى هيجانهاى منفى را در 
بامنظـور ارزيـابى نحـوه تفكـر بعـد از تجربـه (CERQ)

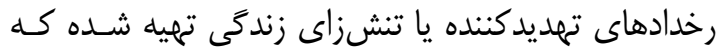

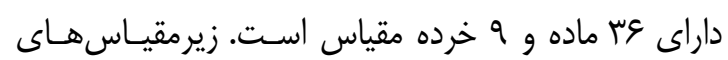

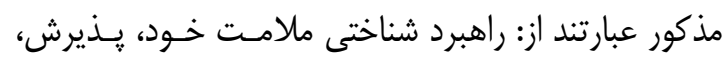

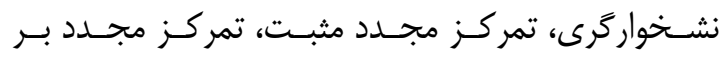

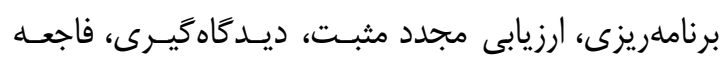

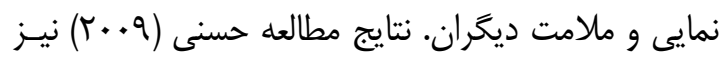

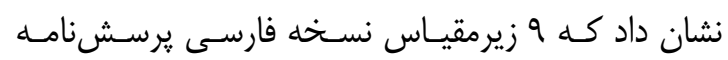

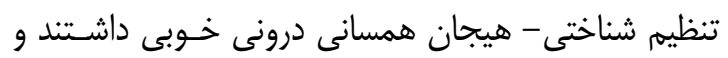

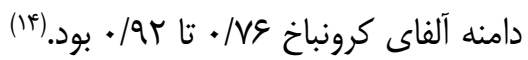

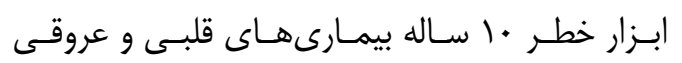

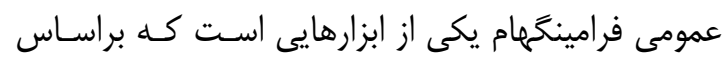

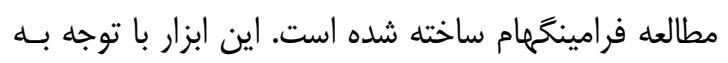
عوامل خطر ابتلا به بيمارىهاى قلبى -عروقى و بـا توجـهـ

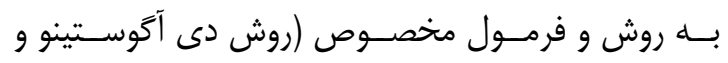

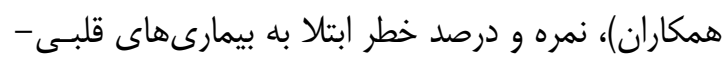

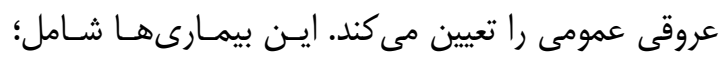

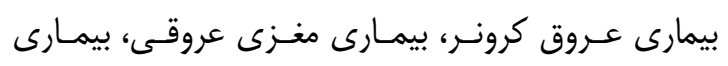

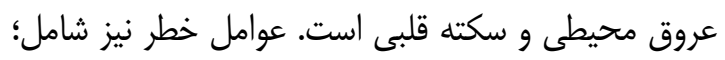

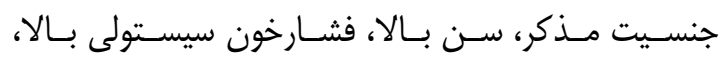

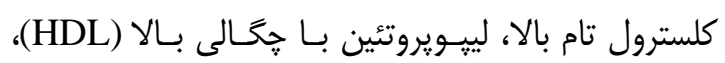
مصرف داروى فشارخون، استعمال سيعار و ديابت هستند.

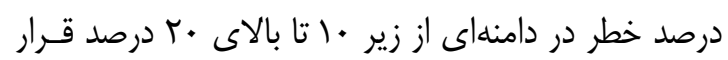

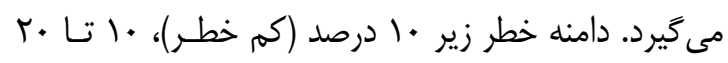

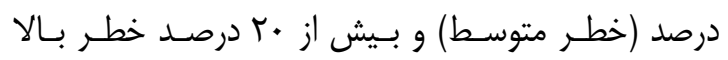

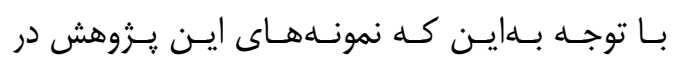

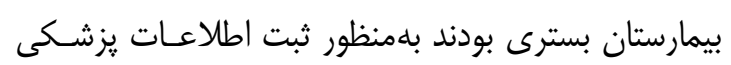

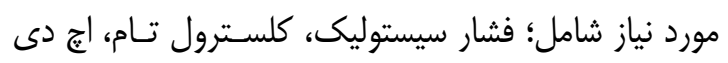

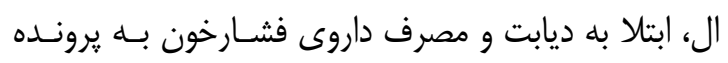
بيماران مراجعه شد. در مورد مصرف سيگار نيز از بيمـاران سؤال شد. سن (سال)، فشارخون سيسـتوليك (ميلـىمتـر

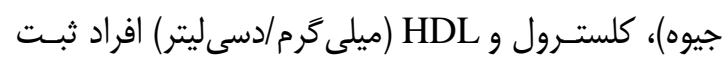

كردن به فارسى روان به طورى كه در تكميل يرسشنامهها

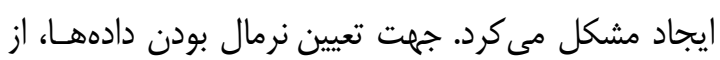

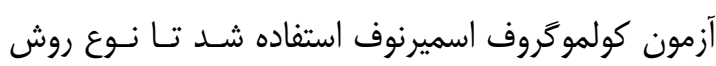

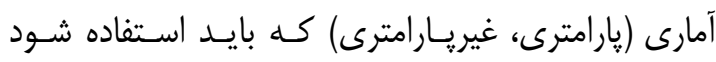

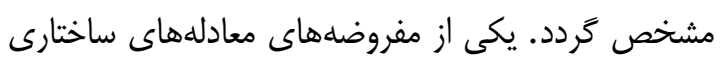

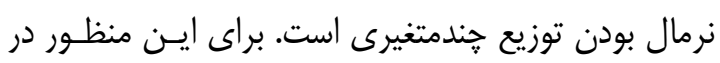

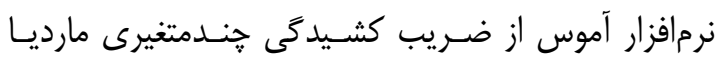

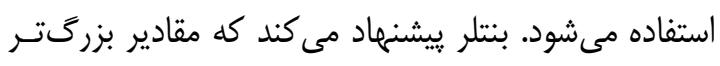

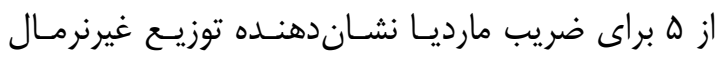

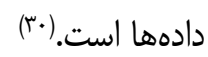

ابزارهاى يزوهش عبارت بودند ازئ يرسشنامهامه وضعيت

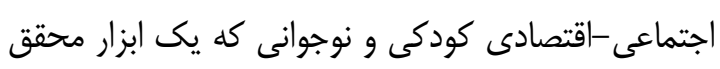

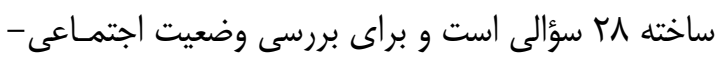

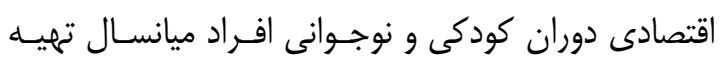

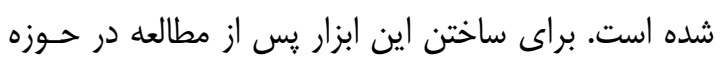

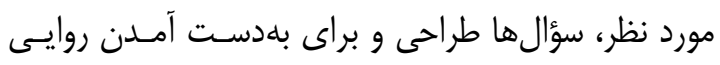

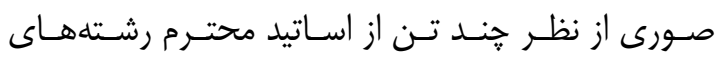

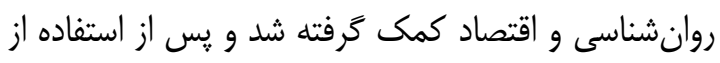

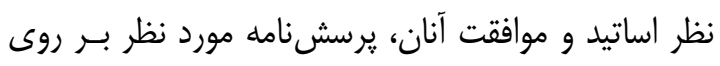

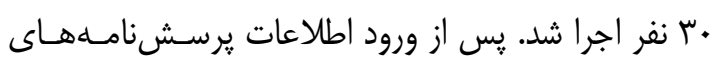

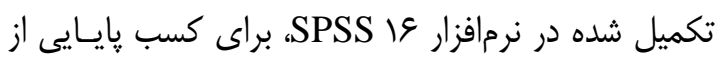

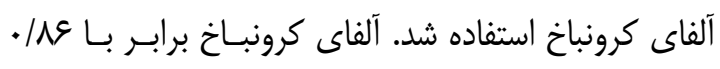

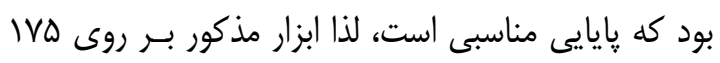

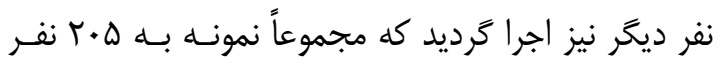
رسيد. سبِ براى بلهدست آوردن روايى سازه ابزار مـذكور

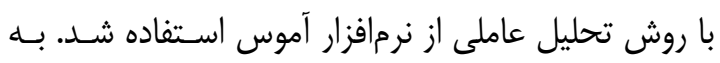

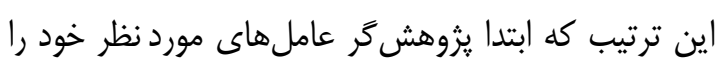

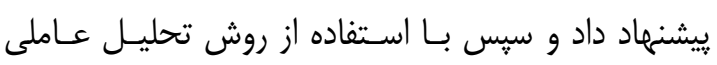

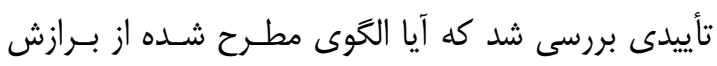

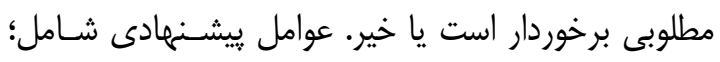

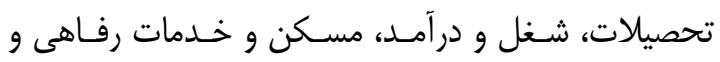

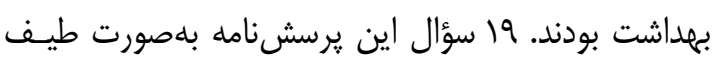

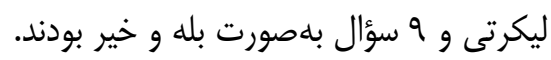

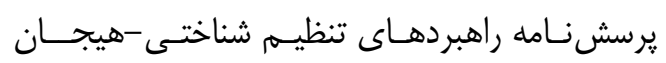


براساس نتايج جدول (مقدارهاى بهدست آمده بـراى اين شاخصها نشان مىدهد كه در مجمـوع و بـا در نظـر

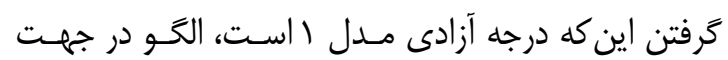

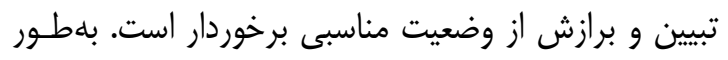

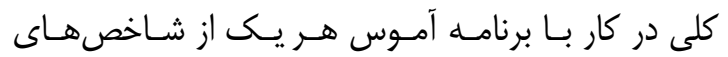

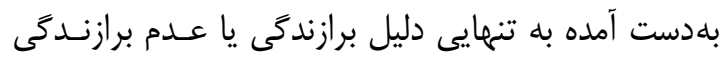

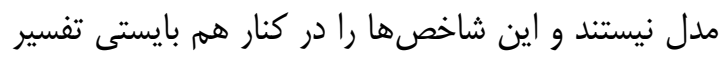

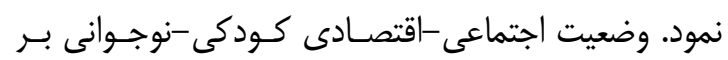
تنظيم شناختى منفى هيجان اثر مسـتقيم معنـادار داشـته

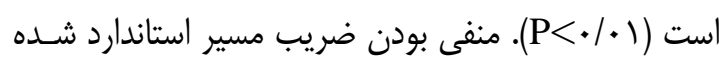

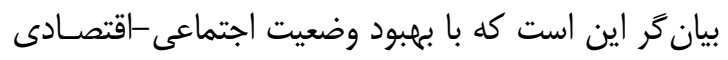

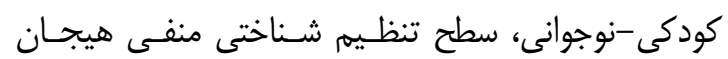
كاهش مىيابد (جدول شماره r).

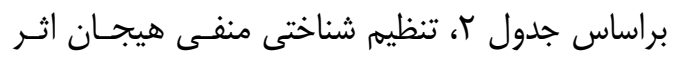

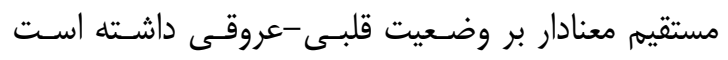

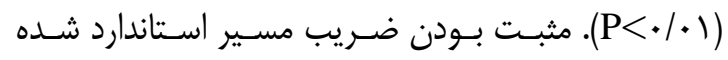

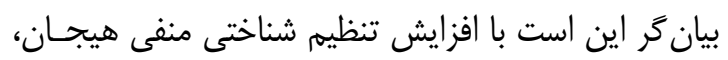

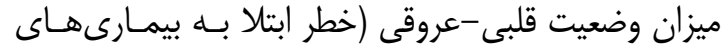

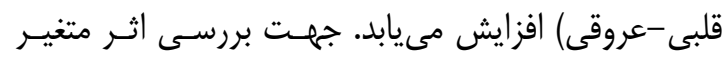

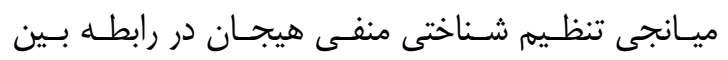

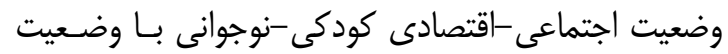

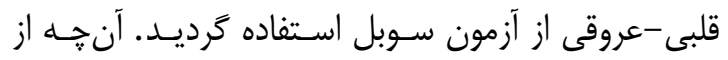

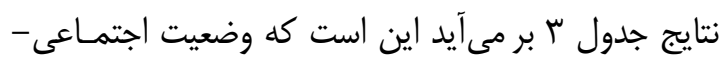

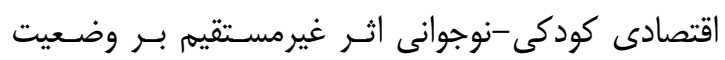

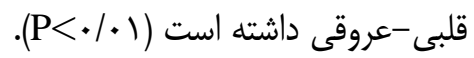

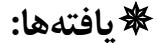

ميانكين وضعيت اجتماعى-|قتصادى كودكى نوجوانى

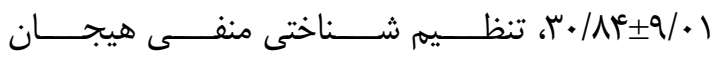


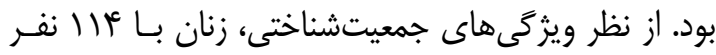
(ه内/\& درصد) فراوانى بيشترى نسبت به مـردان داشـتند.

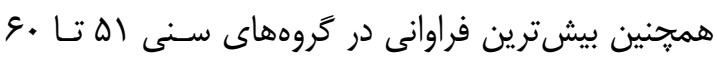

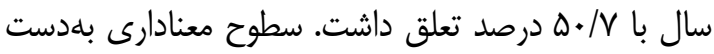
آمده هر يك از متغيرهاى ثزوهش در آزمـون كلمـوكروف اسميرنوف بزرگتر از هـ • • بود، لذا دادههاى تمام متغيرها

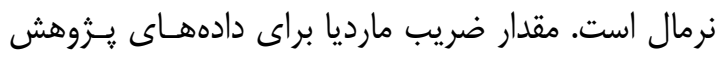

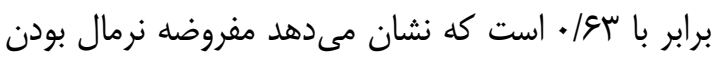
جندمتغيره برقرار است.

\section{جدول ا - شاخصهاى برازش تحليل مسير}

\begin{tabular}{|c|c|c|}
\hline \multicolumn{2}{|c|}{ شاخصهاى برازش } & \multirow{2}{*}{ ن ام شاخص } \\
\hline حد مجاز & مقدار & \\
\hline كمتر از ؟ ك & $r / \Delta T^{\prime}$ & $\frac{\chi^{2}}{d f}$ \\
\hline بالاتر از 9/. &.$/ 91$ & برازندگى تعديل يافته (CFI) \\
\hline بالاتر از 9/. &.$/ 91$ & برازندگى نرم شده (NFI) \\
\hline بالاتر از 9/. &.$/ 94$ & نيكويى برازش (GFI) \\
\hline بالاتر از 9/. &.$/ 9$. & نيكويى برازش اصلاح شده (AGFI) \\
\hline
\end{tabular}

جدول r- ضرايب و معنادارى اثر مستقيم وضعيت اجتماعى-اقتصادى كودكى-نوجوانى بر تنظيم شناختى منفى هيجان و اثر اين مؤلفه بر وضعيت قلبى -عروقى

\begin{tabular}{|c|c|c|c|c|c|c|}
\hline سطح معنى دارى & آماره & م استاندارد شده & ضريب استاندارد نشده & 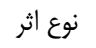 & متغير ييشبين & متغير ملاكى \\
\hline $.1+1$ & $-N / \& V$ &.$- / Q T$ &.$- / 8 \Delta$ & مستقيم & وضعيت اجتماعى -اقتصادى & تنظيمم شناختى منفى هيجان \\
\hline $.1+1$ & $9 / M$ & $\cdot / \Delta V$ & $\cdot 1 \cdot 4$ & مستقيم & تنظيم شناختى منفى هيجان & وضعيت قلبى -عروقى \\
\hline
\end{tabular}


جدول بـ- ضرايب و معنادارى اثر غير مستقيم وضعيت اجتماعى-اقتصادى كودكى-نوجوانى بر وضعيت قلبى-عروقى

\begin{tabular}{|c|c|c|c|c|c|c|}
\hline سطح معنى دارى & آماره & م استاندارد شده & ضريب استاندارد نشده & نوع اثر & متغير بيشبين & متنير ملاك \\
\hline.$/ . .1$ & $-s / V^{e}$ & $-\cdot / \Gamma$. &.$- / . \mu$ & غيرمستقيم (نقش واسطه & وضعيت اجتماعى-اقتصادى & وضعيت قلبى-عروقى \\
\hline
\end{tabular}

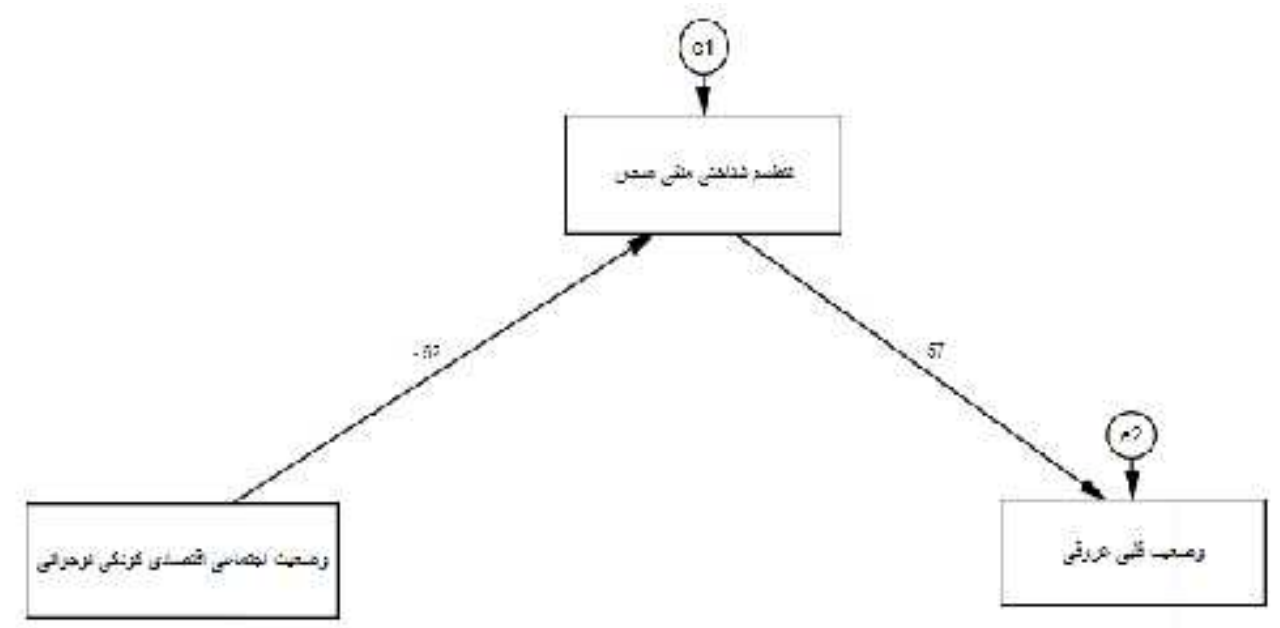

شكل ا - مدل تحليل مسير در حالت ضرايب استاندارد

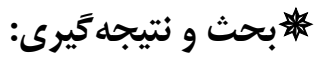

كودكى مىتواند سيستم زيستى را نيز تغيير دهد. تـنش در طبقههاى קإيين مى تواند منجر به كاهش كاركرد خانواده و

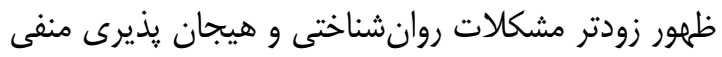

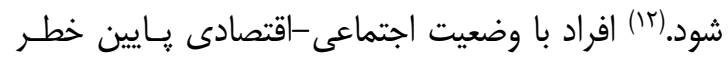

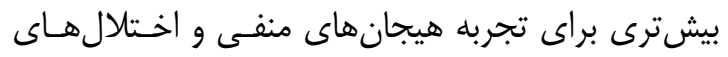

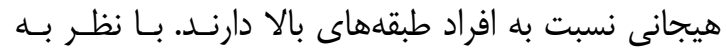

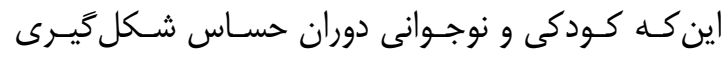

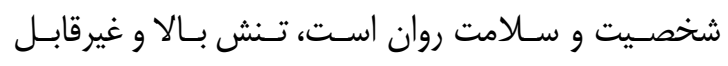
اييشبينى زمينه شكل

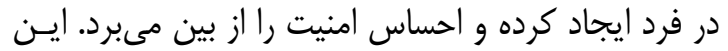

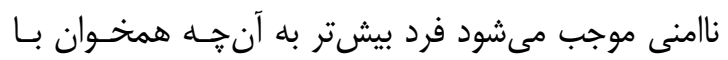

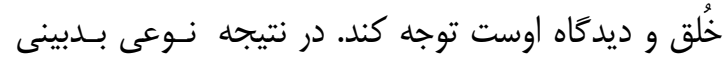

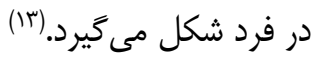

طبـق مطالعـه حاضـر وضـعيت اجتمـاعى -اقتصـادى ديرى كودكى -نوجوانى و تنظيم شناختى منفى هيجان در قالـ

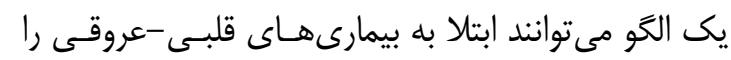

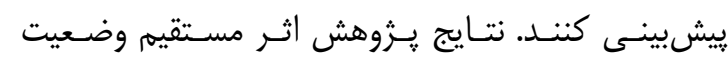
اجتماعى-|قتصادى كودكى -نوجوانى بـر تنظـيم شـناختى

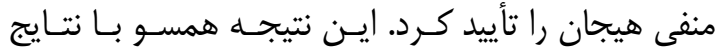

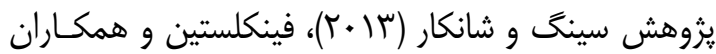
(T)

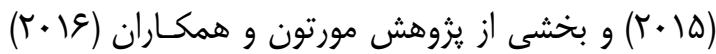

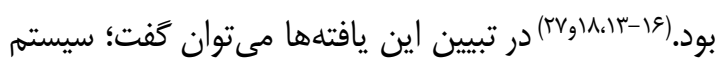
وجـودى انسـان، ابعـاد زيسـتى -روانـى -اجتمـاعى دارد و

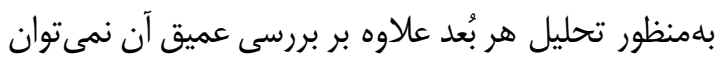

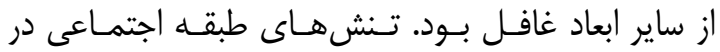


حالى كه ورزش و مصرف غذاى سالم, (مثالى از رفتارهـاى

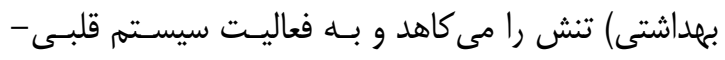

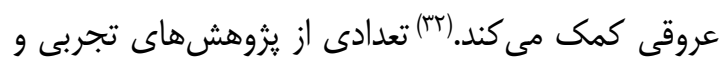

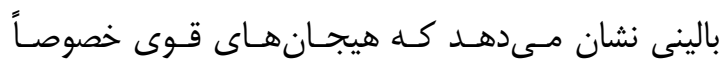

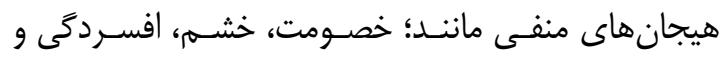

اضطراب بيمارى عروق كرونر را تسريع مى كند.

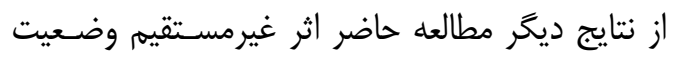

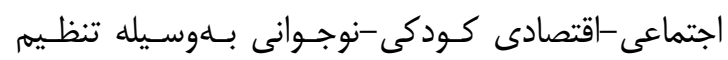

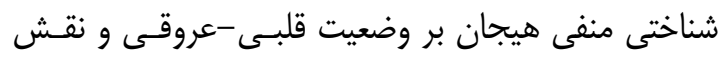

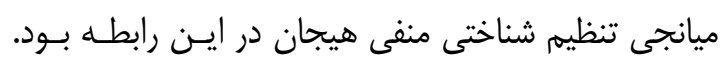

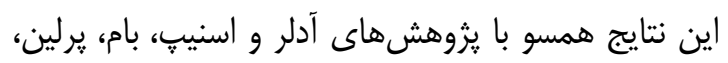

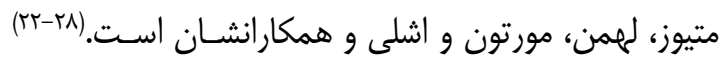

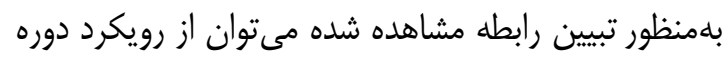
زندگى كمى گرفت. وضعيت اجتمـاعى -اقتصـادى دوران

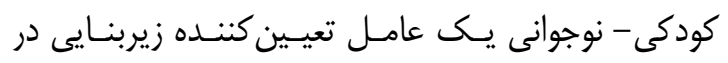

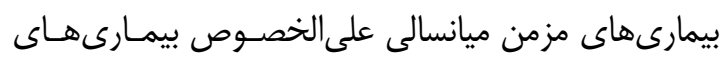

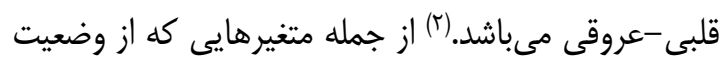

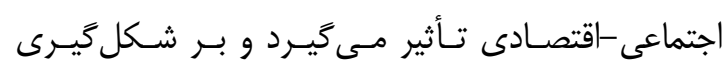

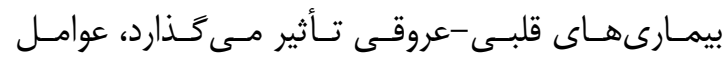

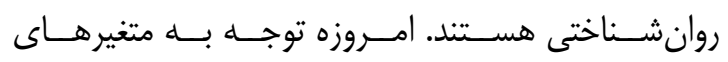
روان شناختى مؤثر بر سلامت افزايش يافته اسـت. در ايسن

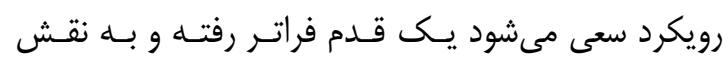
عوامل اجتماعى -اقتصادى نيز توجه شود.

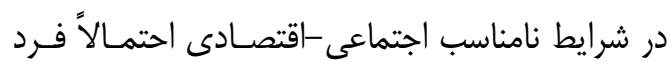

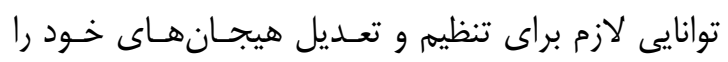

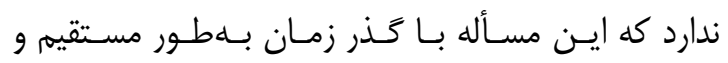

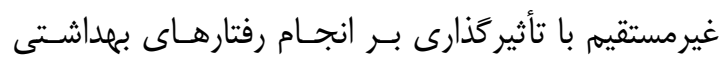

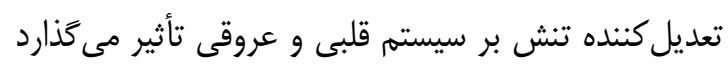

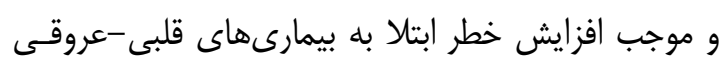

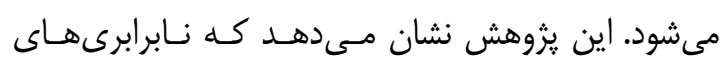

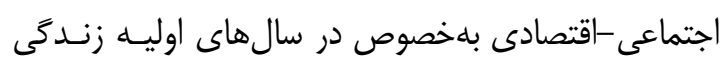

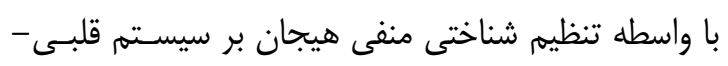

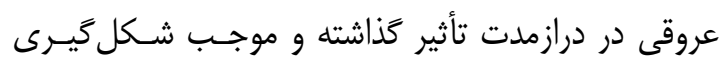
عوامل خطر بيمارىهاى قلبى -عروقى مىشـود. لـذا ايـن
از ديخر نتايج اين يزوهش اثر مستقيم تنظيم شناختى

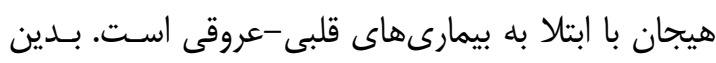

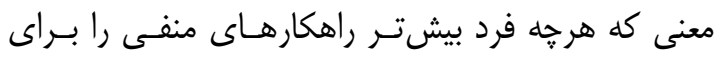

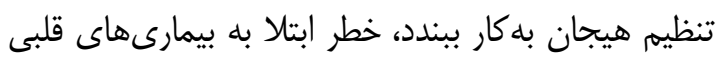

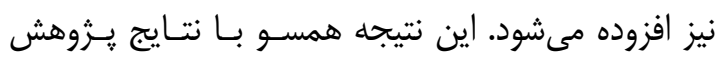

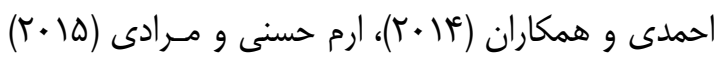

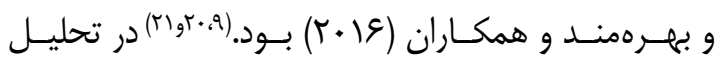

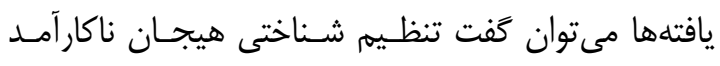

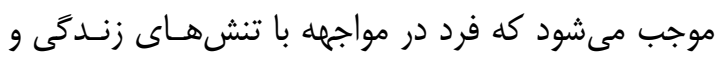

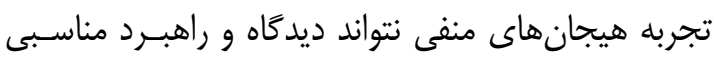

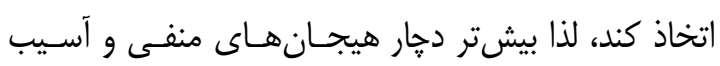
زننده مىشود. بهدنبال تجربه هر نوع هيجـانى (مثبـت يـا

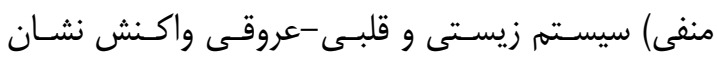

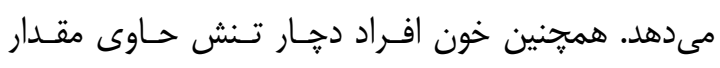

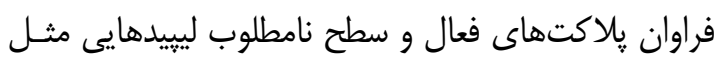

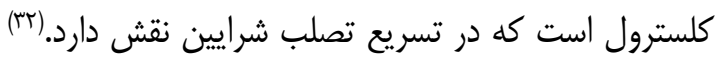

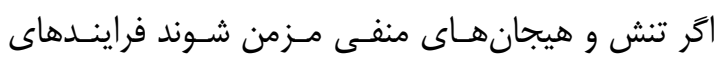

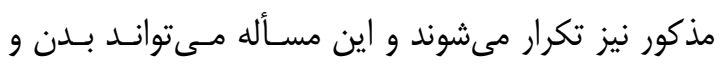

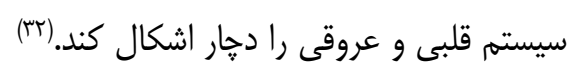
براساس نظر سليه نيز اخر تنش ادامه يابد بدن يس إن از

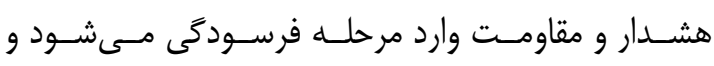

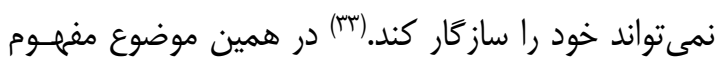
الوستاتيى لود نيز مطرح شده كه حاكى از اثرهاى زيان رانبار

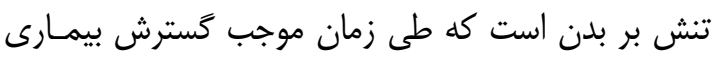

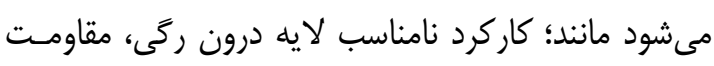

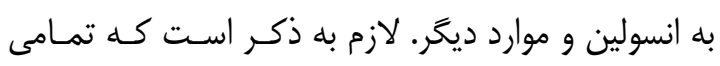

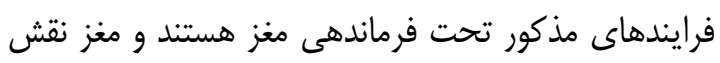

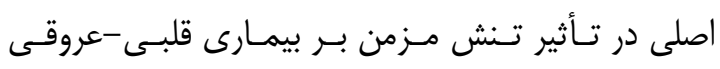

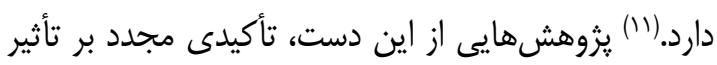

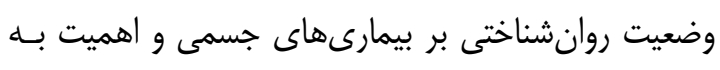
حوزه روانشناسى سلامت است. همجنين رونين تنظيم هيجـان

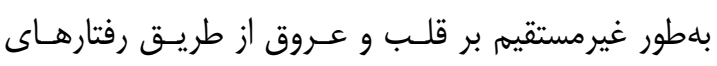

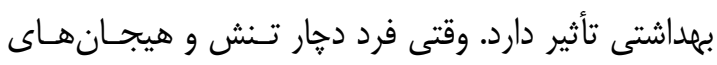

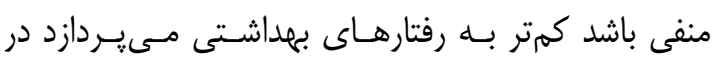




\section{مراجع:}

1. National action plan for prevention and control of non-communicable diseases and the related risk factors in the Islamic Republic of Iran, 2015-2025. Iranian National Committee for NCDs Prevention and Control; 2015. 88-99 [In Persian]

2. A life course approach to health, the implications for training of Embracing. World Health Organization; 2002.

3. Kuh D, Ben-Shlomo Y, Lynch J, Hallaqvist J, Power C. Life course epidemiology. $\mathbf{J}$ Epidemiol Community Health 2003; 57(10): 778-83. doi: 10.1136/ jech.57.10.778.

4. Webba S, Janusa M, Dukua E, Raosa R, Brownellb M, Forerc B, et al. Neighbourhood socioeconomic status indices and early childhood development. SSM Popul Health 2017; 3: 48-56. doi: 10.1016/j.ssmph.2016. 11.006 .

5. Adler NE, Ostrove JM. Socioeconomic status and health: what we know and what we don't. Ann N Y Acad Sci 1999; 896: 3-15. doi: 10.1111/j.1749-6632.1999.tb08101.x.

6. Pollitt RA, Rose KM, Kaphman JS. Evaluating the evidence for models of lifecourse socioeconomic factors and cardiovascular outcomes: a systematic review. BMC Public Health 2005; 5: 7. doi: 10.1186/ 1471-2458-5-7.

7. Lee M, Mahmud Khan M, Wright B. Is childhood socioeconomic status related to coronary heart disease? Evidence from the Health and Retirement Study (1992-2012). Gerontol Geriatr Med 2017; 3: 2333721417696673. doi: 10.1177/ 2333721417696673.

8. Asefzadeh S, Alikhani S, Javadi HR. Socio-economic status and mortality from cardiovascular diseases in. J Qazvin Univ
نابرابرى تكرار شده و موجب شيوع بيشتر مسايل قلبى -

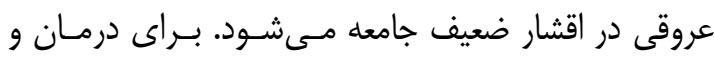

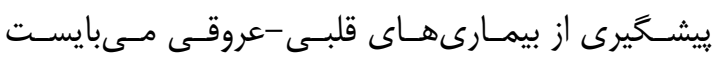

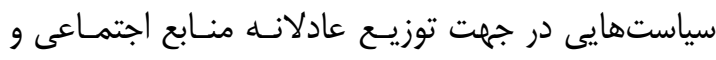

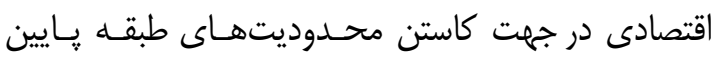

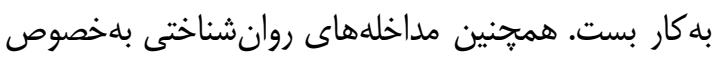

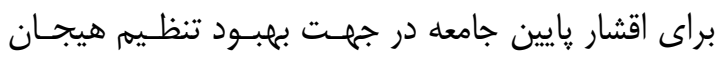
مىتواند در ييشگيرى از بيمارىهاى قلبى -عروقى مـؤثر بائر باشد. از جمله محــدوديتهــاى ايـن هـروهش، دشـوارى و

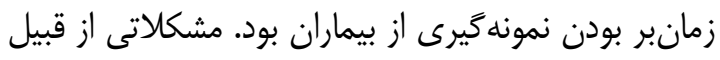

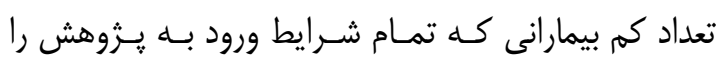

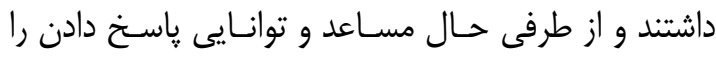

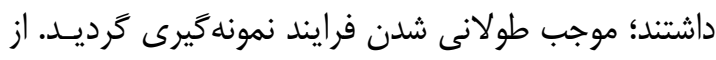

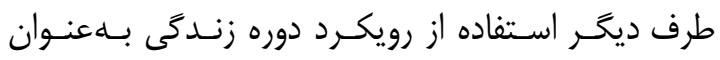

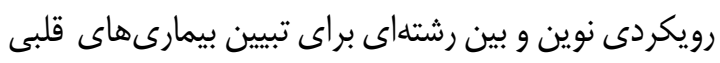

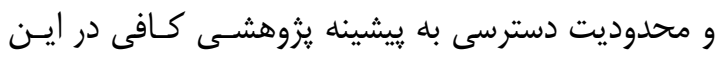

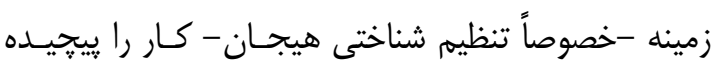

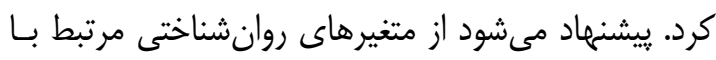

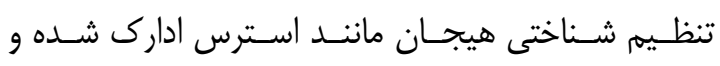

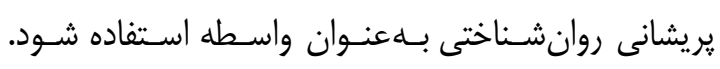

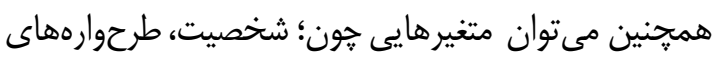

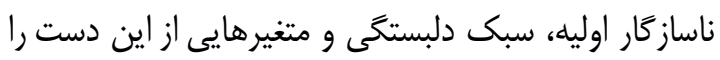

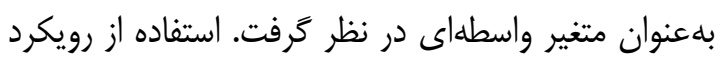

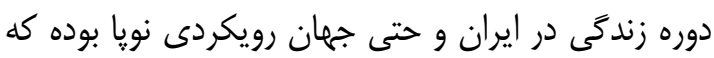

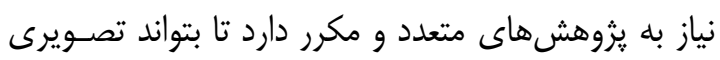
درست از علل مؤثر بر بيمارىهاى مزمن را ترسيهم كند.

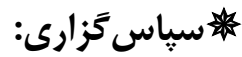

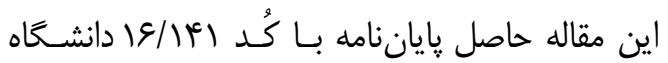

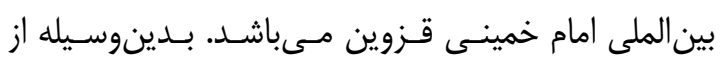

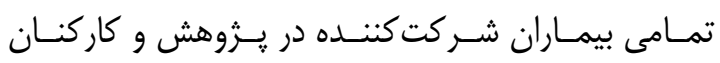
بيمارستان قدردانى مى شود. 
Med Sci 2013; 16(4): 40-6. [In Persian]

9. Pulkki-Raback L, Elovainio M, Hakulinen

C, Lipsanen J, Hintsanen M, Jokela M, et al. Cumulative effect of psychosocial factors in youth on ideal cardiovascular health in adulthood: the cardiovascular risk in young Finns Study. Circulation 2015; 131(3): 24553. doi: 10.1161/CIRCULATIONAHA.113. 007104.

10. Chen E. Why Socioeconomic status affects the health of children. A psychosocial perspective. Curr Dir Psychol Sci 2004; 13(3): 112-5. doi: 10.1111/j.0963-7214.2004. 00286.x.

11. Albert A, Slopen N, Williams DR. Cumulative psychological stress and cardiovascular disease risk: a focused review with consideration of black-white disparities. Curr Cardiovasc Risk Rep 2013; (7): 318-25. doi: 10.1007/s12170-013-0338-5.

12. Poulton R, Caspi A. Commentary: how does socioeconomic disadvantage during childhood damage health in adulthood? Testing psychosocial pathways. Int $\mathbf{J}$ Epidemiol 2005; 34(2): 344-5. doi: 10.1093/ ije/dyi044.

13. Chen E, Langer DA, Raphaelson YE, Matthews KA. Socioeconomic status and health in adolescents: the role of stress interpretations. Child Dev 2004; 75(4): 103952. doi: 10.1111/j.1467-8624.2004.00724.x.

14. Hasani J, Miraghaie A. The relationship between strategies for cognitive regulation of emotions and suicidal ideation. Contemporary Psychology 2012; 7(1): 61-72. [In Persian]

15. Ghasemzade Nassaji S, Peyvastegar M, Hosseinian S, Mutabi F, Banihashemi S. Effectiveness of cognitive-behavioral intervention on coping responses and cognitive emotion regulation strategies in women. J Behavioral Sciences 2010; 4(1):
35-43. [In Persian]

16. Singh S. Shankar B. Socio-economic status of family as a factor of emotion regulation and well-bing. Indian $\mathrm{J}$ Health and Wellbing 2013; 4(8): 1521-4

17. Finkelstein DM, Kubzansky LD, Captiman J, Goodman E. socioeconomic differences in adolescent stress: the role of psychological resources. J Adolesc Health 2007; 40(2): 127-34. doi: 10.1016/j. jadohealth.2006.10.006.

18. Bîlc M, Cioară M, Miu AC. Childhood socioeconomic status and emotion regulation difficulties. 6th International Conference on Emotions, Well-being and Health 2016; Tilburg, NL, 21-7.

19. Ahmadi F, Asqar-nejad-Farid A, Borjali $M$. The comparison of patients suffering from coronary thrombosis with healthy individuals concerning early maladaptive schemas and emotion-regulation strategies. J Behavioral Sciences 2014 8(1): 55-63. [In Persian]

20. Eram S, Hasani G, Moradi A. Comparing of cognitive emotion regulation strategies in patients with coronary artery, implantable cardioverter defibrillator recipients and normal subjects. J Neyshabur Univ Med Sci 2015; 3(3): 29-38. [In Persian]

21. Bahremand M, Alikhani M, Zakiei A, Janjani P, Aghaei A. Emotion risk-factor in patients with cardiac diseases: the role of cognitive emotion regulation strategies, positive affect and negative affect (a casecontrol study). Glob J Health Sci 2016; 8(1): 173-9. doi: 10.5539/gjhs.v8n1p173.

22. Adler NE, Snibbe AC. The role of psychosocial processes in explaining the gradient between socioeconomic status and health. Curr Dir Psychol Sci 2003; 12: 11923. doi: 10.1111/1467-8721.01245.

23. Baum A, Garofalo JP, Yali AM. 
Socioeconomic status and chronic stress. Does stress account for SES effects on health? Ann N Y Acad Sci 1999; 896: 13144. doi: 10.1111/j.1749-6632.1999.tb08111.x. 24. Pearlin LI, Schieman S, Fazio EM Meersman SC. Stress, health, and the life course: some conceptual perspectives. J Health Soc Behav 2005; 46(2): 205-19. doi: $10.1177 / 002214650504600206$.

25. Matthews KA, Raikkonen K, Gallo L, Kuller LH. Association between socioeconomic status and metabolic syndrome in women: testing the reserve capacity model. Health Psychol 2008; 27: 576-83. doi: 10.1037/0278-6133.27.5.576.

26. Lehman BJ, Taylor SE, Kiefe CI, Seeman

TE. Relation of childhood socioeconomic status and family environment to adult metabolic functioning in the CARDIA study. Psychosom Med 2005; 67(6): 846-54. doi: 10.1097/01.psy.0000188443.48405.

27. Morton PM, Turiano NA, Mroczek DK, Ferraro KF. Childhood misfortune, personality, and heart attack: does personality mediate risk of myocardial infarction? $\mathrm{J}$ Gerontol B Psychol Sci Soc Sci 2018; 73(5): 825-35.

28. Winning A, Glymour MM, McCormick MC, Gilsanz P, Kubzansky LD. Childhood psychological distress as a mediator in the relationship between early-life social disadvantage and adult cardiometabolic risk: evidence from the 1958 British Birth Cohort. Psychosom Med 2016; 78(9) 1019-30. doi: 10.1097/PSY. 0000000000000409.

29. Tabachnic B, Fidell L. Using multivariate statistics. 2nd ed. Boston: Allyn and Bacon; 2001. 68-9.

30. Byrne BM. Structural equation modeling with AMOS: basic concepts, applications, and programming. Routledge Pub; 2010.

31. Hariri N, Houshiar-Rad A, Zayeri F, Bondarianzadeh D. Association between alternative healthy eating index and 10-year risk cardiovascular diseases in male employees in the public sector in Tehran, 1391. Iran J Nutr Sci Food Technol 2013; 8(2): 41-50. [In Persian]

32. Sarafino EP. Health psychology. Translated by: Seyed Mohammsdy Y. 4th ed. Tehran, Roshd pub. 2002. 220-5. [In Persian] 33. Kalat JW. Biological psychology. Translated by: Seyed Mohammadi Y. 9th ed. Tehran. Razan Pub; 2007. 80-5 [In Persion] 34. Vlachakis D, Vlachakis C. Understanding of emotions and cardiovascular related diseases. Peer J Pre Prints 2014; 27: 1-41. doi: 10.7287/peerj.preprints.761v1. 